Ulung Pribadi ${ }^{1}$, Juhari

Sasmito $\mathrm{Aji}^{2}$, Rossi Maunofa Widayat $^{3}$

12 Fakultas IImu Sosial dan Politik, Universitas Muhammadiyah Yogyakarta Jalan Brawijaya, Geblagan, Tamantirto, Kasihan, Bantul,

Daerah Istimewa Yogyakarta

3Universitas Muhammadiyah Mataram, Jalan KH. Ahmad Dahlan No.1, Pagesangan, Kecamatan Pagesangan,

Kota Mataram

Email : widayatrossi@gmail.com

\section{Inisiasi Pendirian dan Pengelolaan Bank Sampah}

\author{
DOI: $10.18196 /$ berdikari.v9i2.9725
}

\begin{abstract}
Environmental conservation is a shared responsibility for the government, private companies, and the community. One of the efforts to protect the environment is to pay attention to waste disposal. Household contribution to waste generation ranks first compared to other sectors. Therefore, efforts should be made to develop public awareness of waste management. The implementation of the service program aimed to build awareness and management of waste originating from household activities. The methods in the community service program were through tutorials and mentoring. The results of the program showed that the community's more concerned and aware of the importance of waste management. The main indicator of improved community concern was the establishment of the "Kluwih Resik" Waste Bank.

Keywords: Waste Bank, Initiation, Youth Organization [BS1], Waste Management
\end{abstract}

\begin{abstract}
ABSTRAK
Pelestarian lingkungan hidup menjadi tanggungjawab Bersama, baik pemerintah, swasta, maupun masyarakat. Salah satu upaya memelihara lingkungan yakni kepeduliaan terhadap keberadaan sampah. Kontribusi rumah tangga terhadap timbulan sampah menduduki peringkat pertama dibandingkan kegiatan yang lain. Oleh karena itu, perlu diupayakan pembangunan kepeduliaan masyarakat akan pengelolaan sampah. Implementasi program pengabdian bertujuan untuk membangun kepeduliaan dan pengelolaan sampah yang bersumber dari aktivitas rumah tangga. Metode yang digunakan dalam program pengabdian kepada masyarakat yakni tutorial dan pendampingan. Hasil program menunjukkan bahwa kepedulian dan kesadaran masyarakat mitra terhadap pentingnya pengelolaan sampah. Indikator utama kepeduliaan masyarakat, yaitu terbangunya Bank Sampah "Kluwih Resik".

Kata Kunci : Bank Sampah, Inisiasi, Karang Taruna[BS1], Pengelolaan Sampah
\end{abstract}

\title{
PENDAHULUAN
}

Sampah merupakan salah satu masalah sosial yang dihadapi setiap orang yang bertempat tinggal di desa maupun kota. Keberadaan sampah dapat menimbulkan persoalan lingkungan jika tidak tertangani dengan baik (Safiah, \& Julipriyanto, 2017). Menurut Slamet (2002) sampah adalah sisa kegiatan sehari- hari manusia atau bisa juga 
proses alam yang berbentuk padat, ataupun semi padat berupa zat organik atau anorganik yang dapat terurai dan tidak dapat terurai yang dianggap sudah tidak berguna lagi dan dibuang ke lingkungan. Penggunaan kemasan sekali pakai berbahan plastik adalah salah satu contoh penghasil sampah yang ada di masyarakat kita saat ini. Selain itu, masih banyak aktifitas alam dan manusia yang akhirnya menghasilkan sampah yang jika semua itu dibiarkan terus menerus akan mengganggu aktifitas manusia dan akan merusak alam (Kusuma \& Astuti, 2017).

Jenis-jenis sampah yang ada di sekitar kita sangat banyak, seperti sampah rumah tangga, sampah industri, sampah peternakan, sampah perkebunan, sampah pasar, sampah kantor dan perusahaan, adalah beberapa contoh jenis sampah yang dikelompokkan menurut sumbernya. Untuk mengurangi volume sampah yang semakin bertambah, berbagai cara dilakukan oleh pemerintah setempat, seperti halnya membuat pupuk kompos dan mendaur ulang sampah menjadi alat-alat rumah tangga atau lainnya yang dapat dimanfaatkan lagi. Namun, penanggulanan tumpukan sampah tersebut belum menimbulkan dampak atau gerakan yang serupa di masyarakat. Kesadaran akan pentingnya menjaga lingkungan masih belum terlihat di masyarakat sehingga masih banyak ditemukan tumpukan sampah di mana-mana (E. Suryani, 2016).

Undang-Undang Nomor 18 Tahun 2008 tentang Pengelolaan Sampah merupakan salah satu kegiatan pemberdayaan masyarakat, yakni pengelolaan sampah. Pengelolaan sampah adalah kegiatan yang sistematis, menyeluruh, dan berkesinambungan yang meliputi pengurangan dan penanganan sampah. Pengelolaan sampah diselenggarakan berdasarkan asas tanggung jawab, asas berkelanjutan, asas manfaat, asas keadilan, asas kesadaran, asas kebersamaan, asas keselamatan, asas keamanan, dan asas nilai ekonomi. Pengelolaan sampah bertujuan untuk meningkatkan kesehatan masyarakat dan kualitas lingkungan serta menjadikan sampah sebagai sumber daya (Kusuma \& Astuti, 2017).

Dusun Kluwih yang terletak kurang lebih 10 km dari pusat Kota Yogyakarta, ke arah barat menuju Kabupaten Kulon Progo mempunyai lingkungan pedesaan yang cukup asri, dengan rata-rata mata pencaharian penduduknya adalah bertani, beternak, serta memelihara ikan air tawar. Sebagian lagi penduduknya berprofesi sebagai buruh, pekerja serabutan, serta berdagang. Dusun ini terdiri atas 4 RT dan 2 RW, di bawah administrasi Desa Balecatur, Kecamatan Gamping, Kabupaten Sleman. Setiap RT dihuni rata-rata 30 hingga 40 kepala keluarga yang di dalamnya masing-masing dihuni antara 3 sampai 5 anggota keluarga.

Semula Dusun Kluwih cukup subur dan masyarakatnya banyak bertani. Sebagian kebun (tanah kosong) di sekitar rumah banyak tumbuh tanaman-tanaman produktif, 


\section{9}

seperti pisang, manga, rambutan, kelapa, nangka, dan lain sebagainya. Akan tetapi, belakangan ini produktifitas tanaman di area persawahan mulai menurun. Penurunan produktifitas juga dipengaruhi oleh terganggunya saluran irigasi yang mengairi sawahsawah dan berkurangnya penggunaan pupuk pabrikan yang harganya cukup tinggi. Sementara itu, produktifitas tanaman yang ada di kebun-kebun dekat rumah juga semakin berkurang yang diakibatkan oleh semakin sempitnya lahan (digunakan untuk membangun rumah tinggal), semakin sedikitnya humus yang diberikan, serta kualitas tanah yang semakin rendah.

Dampak penggunaan bahan-bahan kebutuhan dalam rumah tangga yang semakin menambah sampah berpengaruh terhadap lingkungan sekitar. Banyak juga masyarakat yang belum menyadari bahwa sampah-sampah tersebut menjadikan kualitas lingkungan menurun, bahkan menambah kotor dan kurang sehatnya lingkungan. Sebagai contoh bagi sebagian besar masyarakat memiliki limbah kotoran ternak (sapi, kerbau, kambing, ayam, itik) maupun limbah-limbah dari dedaunan maupun sisa-sisa ma kanan dan sayuran dari masyarkat. Mereka banyak membuang sampah-sampah tersebut dan membiarkannya. Hal ini di samping akan menghasilkan bau busuk juga berpotensi mendatangkan bibit penyakit, khususnya di saat musin hujan. Masyarakat selama ini hanya membiarkan limbah-limbah tersebut karena belum mengerti bahwa limbah kotoran ternak, rumah tangga, serta perkebunan jika dikelola akan menjadi pupuk kompos yang kita kenal dengan istilah composting yang bernilai tinggi dan bisa dimanfaatkan untuk memupuk tanaman-tanaman yang ada disekitar Dusun Kluwih.

Selama ini masyarakat kurang peduli dan mungkin tidak tahu cara mengelola dan memanfaat limbah-limbah tersebut untuk keperluan yang lebih produktif. Pengetahuan mereka sangat rendah karena ketiadaan pihak yang mengajari (mengedukasi). Selain itu, ketidakmampuannya dalam mencari informasi (jaringan internet terbatas) dan keterampilan yang rendah (SDM), serta terbatasnya tempat untuk memanfaatkan dan mengolah limbah-limbah tersebut. Sementara itu, kita tahu bahwa sebenarnya limbah (sampah-sampah), baik yang berasal dari alam maupun sampah rumah tangga dan limbah kotoran ternak mempunyai potensi atau nilai ekonomi yang cukup tinggi kalau dikelola dengan baik, benar, dan profesional.

Jika sampah-sampah yang ada dikelola dengan baik, misalnya dengan mendirikan bank sampah maka akan mendatangkan manfaat yang cukup besar bagi ekonomi maupun lingkungan mereka. Faktor kunci keberlanjutan pengelolaan sistem bank sampah hanya akan terjadi jika sistem tersebut dirawat oleh para stakeholder yang terkait dengan sistem pemberdayaan masyarakat dalam bank sampah. Salah satu praktik terbaik yang dapat 
dilakukan oleh bank sampah yang sudah mengarah kepada keberlanjutan adalah menciptakan sistem pengukuran yang koheren dan pemberian penghargaan kepada mentor dan pengurus yang dapat membimbing dan memotivasi perilaku seluruh anggota bank sampah, juga mampu menjaring kerjasama secara positif dengan pihak pemerintah dan lembaga lainnya dalam mencapai sasaran dari keberlanjutan (Kristina, 2014).

Hingga saat ini masyarakat Dusun Kluwih belum mendirikan bank sampah karena masyarakatnya belum memiliki pengetahuan dan pengalaman mengelola sampah-sampah tersebut. Untuk itu, pengabdi merasa perlu untuk memberikan sosialisasi dampak positif pengelolaan sampah bagi kebersihan, kesehatan, dan kenyamanan lingkungan. Pengabdi mengadakan pelatihan bagi masyarakat Dusun Kluwih dalam mengelola sampah hingga menjadi pupuk kompos. Selain sosialisasi dan pelatihan, pengabdi juga akan mendampingi masyarakat sampai terbentuknya bank sampah di Dusun Kluwih. Dengan menginisiasi pendirian bank sampah maka persoalan sampah yang ada di Dusun Kluwih diharapkan akan terselesaikan dengan dengan baik sehingga lingkungan akan menjadi sehat dan asri kembali, serta adanya nilai ekonomi dari keberadaan bank sampah yang diperuntukan bagi pengelola bank sampah maupun bagi masyarakat.

\section{METOdE PELAKSANAAN}

Agar masyarakat Dusun Kluwih bisa terbebas dari persoalan sampah, baik sampah alami maupun sampah buatan, serta dapat mengatasi permasalahan yang ada maka pengabdi menawarkan beberapa tahapan, di antaranya langkah pertama, yaitu sosialisasi yang dilakukan dengan edukasi tentang pentingnya pemeliharaan dan pengelolaan lingkungan agar tetap nyaman dan asri. Sosialisasi meliputi materi tentang akibat-akibat dari sikap merusak lingkungan dengan membuang sampah sembarangan. Materi sosialisasi diberikan dengan metode diskusi (tanya jawab antara pemateri dan masyarakat yang menjadi kelompok sasaran) oleh narasumber pegiat dan pecinta lingkungan. Jumlah peserta meliputi perwakilan warga yang ada di Dusun Kluwih. Langkah kedua adalah pelatihan. Pelatihan yang dimaksud adalah melatih sebagian besar masyarakat Dusun Kluwih untuk mengelola sampah hingga menjadi pupuk kompos. Langkah ketiga adalah pendampingan, yaitu mendampingi masyarakat dalam menyusun struktur pengurus untuk mendirikan bank sampah di Dusun Kluwih.

Terkait permasalahan yang terjadi pada masyarakat mitra dan beberapa tahapan program sebagaimana yang telah diuraikan di atas, pengabdian masyarakat ini fokus pada "Inisiasi Pendirian dan Pengelolaan Bank Sampah dan Composting di Dusun Kluwih, Bale Catur, Gamping Sleman”. Kegiatan dilaksanakan selama enam bulan, yaitu bulan 
Februari Juli 2020. Sebelum pelaksanaan kegiatan, tim pengabdian melaksanakan beberapa persiapan yang diantaranya, dikusi bersama mitra, yaitu masyarakat Dusun Kluwih. Dari diskusi tersebut dirumuskan berbagai program kegiatan berikut ini.

1. Penyusunan jadwal agenda

Persiapan ini dilakukan untuk menyusun jadwal-jadwal kegiatan bersama masyarakat Dusun Kluwih agar jadwal agenda yang sudah dipersiapkan dapat disepakati bersama dan dilaksanakan atas dasar tanggung jawab bersama selama enam bulan.

2. Persiapan sarana dan prasarana

Persiapan ini dilakukan antara tim pengabdian masyarakat bersama bebeberapa masyarakat Dusun Kluwih yang nantinya dapat berkoordinasi dengan kepala dukuh terkait ketersediaan sarana dan prasarana selama proses kegiatan.

3. Kordinasi lapangan

Persiapan ini dilakukan dengan melibatkan karang taruna yang ada di Dusun Kluwih yang memiliki peran dalam setiap kegiatan sehingga diharapkan semua proses kegiatan berjalan dengan lancar. Dalam setiap kegiatan, anggota tim memiliki tugas dan tanggung jawab yang berbeda-beda.

4. Sosialisasi

Sosialisasi ini dilakukan tim pengabdian dengan mengundang stakholders, di antaranya Kepala Dukuh Dusun Kluwih dan pengurus karang taruna dengan tujuan pemberitahuan terkait kegiatan pengabdian masyarakat ini serta menerima masukan dari berbagai pihak mengenai program-program yang akan dilaksanakan.

Bentuk kegiatan pada tahap pelaksanaan berupa sosialisasi materi-materi mengenai bank sampah dan composting, tugas-tugas pokok dan fungsi, pelatihan dalam pengelolaan sampah dan anggaran, manfaat dari sampah yang dikelola, serta cara menyosialisasikan kepada masyarakat. Pendampingan dalam penyusunan program-program kerja dan kegiatan bagi segenap para pengurus dan anggotanya hingga terbentuknya bank sampah di Dusun Kluwih dilaksanakan selama enam bulan (Februari-Juli). Tahap evaluasi dilakukan bersama dengan pelaksanaan semua kegiatan yang kemudian dievaluasi sehingga dapat mengetahui capaian yang sudah atau yang belum dari setiap proses kegiatan. Apabila dalam monitoring dan evaluasi ditemukan adanya kesalahan dan kendala maka bisa segera di perbaiki.

\section{HASIL DAN PEMBAHASAN}

Desa Balecatur adalah sebuah desa yang terletak di Kecamatan Gamping, Kabupaten Sleman, DIY. Proses terbentuknya Desa Balecatur berdasarkan maklumat pemerintah 
Daerah Istimewa Yogyakarta pada tahun 1946 mengenai Pemerintah Kelurahan. Desa Balecatur memiliki delapan belas padukuhan (padukuhan terbanyak di antara desa-desa lain di Kecamatan Gamping). Berdasarkan data yang diperoleh dari Kecamatan Gamping, ada 30 titik pembuangan sampah ilegal yang tersebar di berbagai desa. Di Desa Balecatur terdapat tiga titik limbah pembuangan sampah ilegal yang tersebar di lahan kosong. Hal ini menunjukkan bahwa sampah telah menjadi persoalan di berbagai desa yang ada di DIY.

Sejak kedatangan tim pengabdi, semangat masyarakat Dusun Kluwih melalui Karang Taruna Swayasatwika terlihat sudah siap untuk menjadi ujung tombak pengelolaan sampah di Dusun Kluwih. Selama program pengabdian masyarakat, peran dan kontribusi Karang Taruna Swayasatwika sangat besar. Pengurus karang taruna adalah muda-mudi warga Dusun Kluwih yang usianya rata-rata 1923 tahun. Kegiatan yang mulai dilakukan oleh tim pengabdi sejak tanggal 18 Februari 2020 adalah observasi awal atau persiapan awal. Sebelum pelaksanaan, tim pengabdi berkunjung ke rumah Kepala Dusun, yaitu Bapak Sujiyo. Pada saat kunjungan pertama, tim disambut oleh Kepala Dusun dan pengurus karang taruna. Sejak pertemuan pertama telah disepakati bahwa kegiatan ini akan melibatkan Karang Taruna Swayasatwika dalam semua kegiatan yang sudah diagendakan untuk dilaksanakan pada setiap bulannya (Maret Mei).

Pelaksanaan pengabdian masyarakat di Dusun Kluwih sempat tertunda lima bulan (Maret-Juli) karena masa pandemi covid-19. Situasi ini telah membuat seluruh kegiatan sempat terhenti karena belum adanya tanda penurunan penyebaran virus corona covid19. Dengan mempertimbangkan situasi dan kondisi, tim mencoba untuk berkunjung kembali ke Dusun Kluwih pada tanggal 5 Agustus 2020.

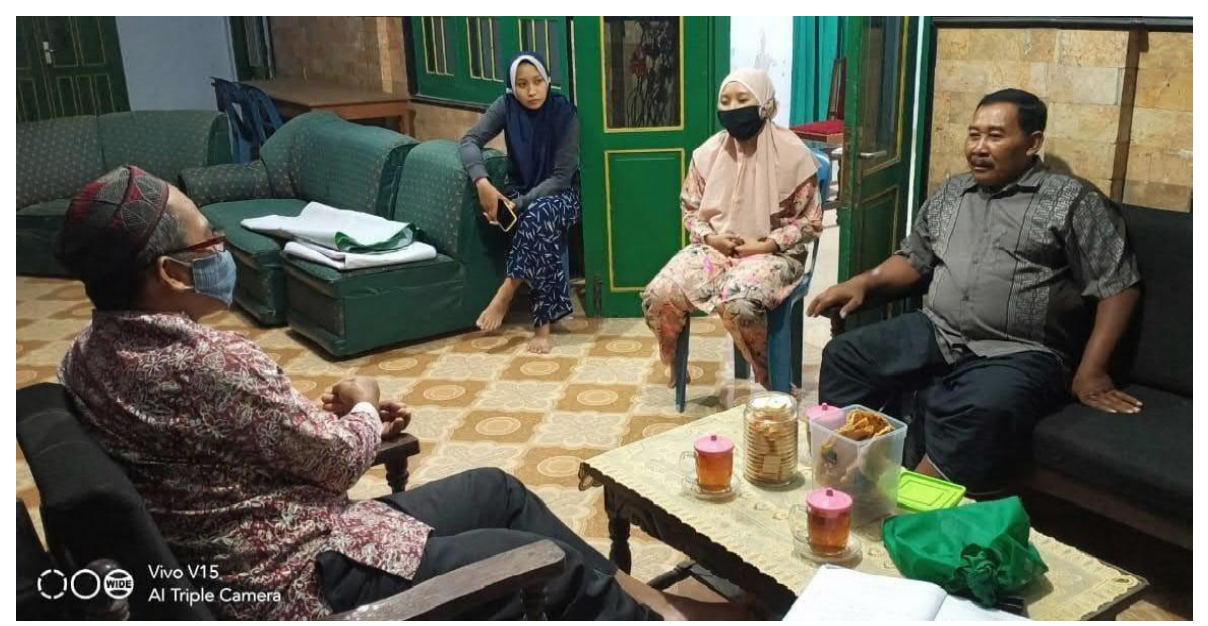

Gambar 1 : Persiapan Kegiatan Sosialisasi dan Pendampingan 


\section{3}

Gambar 1 menunjukkan bahwa kunjungan kedua ini mencoba untuk membahas agenda yang sempat tertunda selama lima bulan. Pertemuan ini menghasilkan kesepakatan bahwa untuk agenda kegiatan sosialisasi serta pendampingan akan tetap dilaksanakan dengan jumlah peserta yang tidak lebih dari 15 orang dengan mematuhi protokol covid-19 dan kegiatan akan dilaksanakan pada tanggal 22 Agustus 2020 bertempat di kediaman Kepala Dusun pukul 19.30 WIB. Bertindak sebagai kordinator saat kegiatan, yaitu pengurus dari Karang Taruna Swayasatwika. Sedangkan kegiatan pelatihan pengelolaan sampah tidak bisa dilaksanakan karena situasi dan kondisi yang belum kondusif, mengingat masih tingginya jumlah penularan covid-19 di DIY setelah pembatasan sosial berskala besar (PSBB) diberlakukan. Hal ini merupakan kesepakatan tim pengabdi dan Kepala Dusun Kluwih. Pelaksanaan kegiatan sosialisasi dan pendampingan pembuatan bank sampah yang dilaksanakan pada tanggal 22 Agustus Pkl. 19.30 WIB dihadiri oleh seluruh tim pengabdi, perwakilan pengurus Karang Taruna Swayasatwika dan beberapa perwakilan masyarakat yang ada di sekitar kediaman Kepala Dusun. Kegiatan ini dilaksanakan dengan tetap mengikuti standar protokol kesehatan.

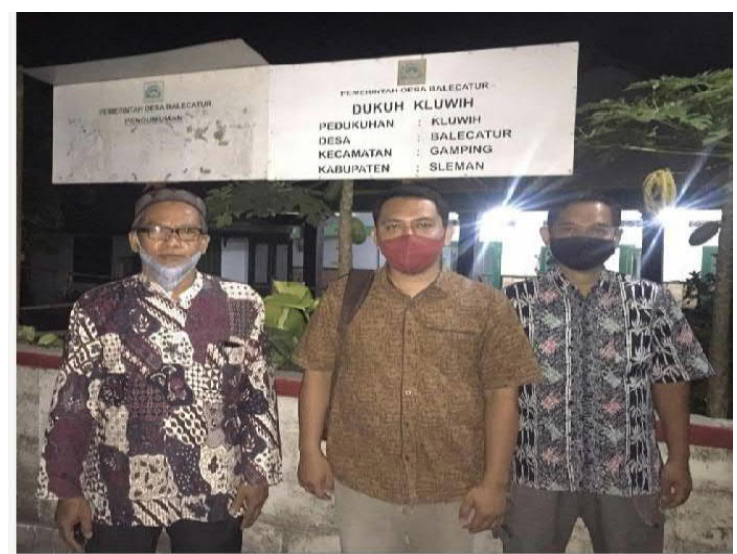

Gambar 2 : Tim Pengabdi di Dusun Kluwih[BS4]

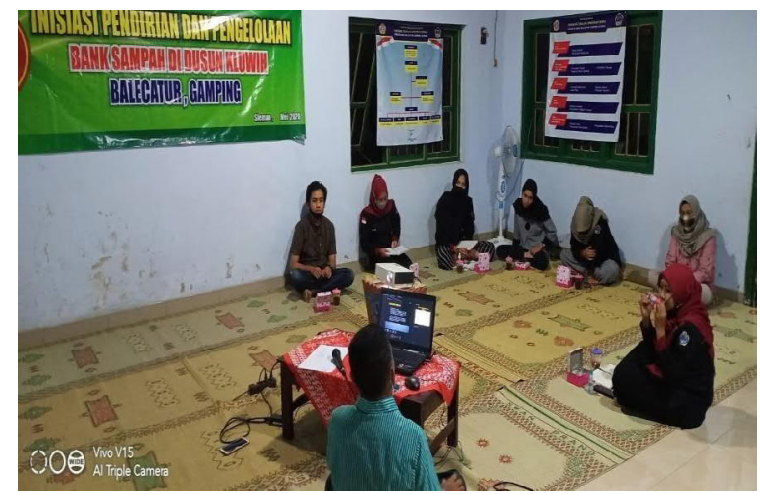

Gambar 3 : Pengurus Karang Taruna Mengikuti Kegiatan Sosialisasi[BS5] 
Dari gambar 2, dan 3 menunjukkan bahwa tim pengabdi melaksanakan kegiatan sosialisasi dengan mematuhi standar potokol covid-19. Tim pengabdi juga tetap melaksanakan kegiatan walaupun jumlah yang hadir kurang dari 15 orang. Kegiatan ini juga turut mengundang narasumber, yaitu Bapak Ahamd Zaenal Fanani, SPd., M.A. yang menyampaikan materi mengenai bank sampah dan composting, tugas-tugas pokok dan fungsi struktur bank sampah, manfaat dari sampah yang dikelola, serta cara menyosialisasikan ke masyarakat. Beberapa hal penting mengenai pengelolaan sampah menurut narasumber, yaitu pengelolaan sampah berbasis masyarakat sebagai suatu pendekatan pengelolaan sampah yang didasarkan pada partisipasi aktif masyarakat. Pemerintah dan lembaga lainnya hanyalah sebagai motivator dan fasilitator. Pengelolaan sampah berbasis masyarakat sangat penting karena kegiatan tersebut dilakukan oleh anggota komunitas itu sendiri. Mereka mengambil keputusan yang terkait dengan kehidupan mereka sendiri. Hal ini akan menjadi lebih tepat guna jika disesuaikan dengan kebutuhan lokal serta prioritas dan kapasitas mereka. Secara spesifik narasumber menyebutkan bahwa program pengelolaan sampah berbasis masyarakat sering kali gagal karena rendahnya partisipasi masyarakat yang sudah berumah tangga. Apabila pengelolaan sampah tidak dianggap sebagai suatu kebutuhan maka akan berimbas pada partisipasi dan kesediaan membayar yang rendah. Kegiatan pengelolaan sampah berbasis masyarakat dapat terus berlanjut apabila terjadi perubahan perilaku warga yang mengelola sampahnya secara mandiri, disertai pengorganisasian masyarakat yang salah satu unitnya adalah Rukun Warga.

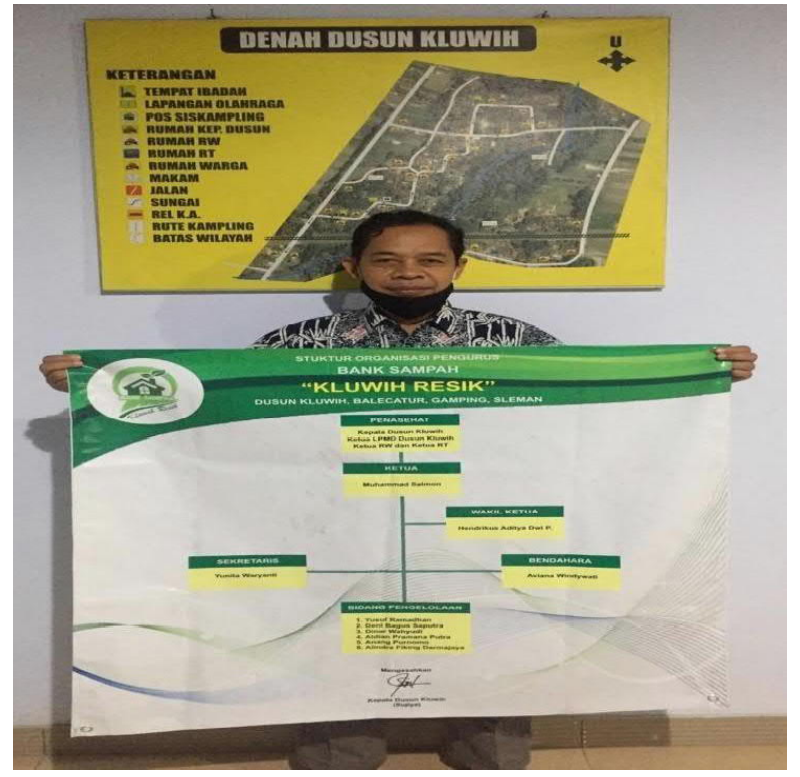


Penyampaian materi dari Bapak Zainal memberikan dampak positif kepada mudamudi yang tergabung dalam organisasi Karang Taruna Swayasatwika, yaitu bertambahnya semangat pengurus karang taruna untuk mau mengambil peran dalam pengelolaan sampah yang ada di Dusun Kluwih. Semangat dan komitmen dari muda-mudi Dusun Kluwih memberikan harapan bahwa persoalan sampah saat ini menjadi tanggung jawab mereka karena masyarakat Dusun Klusih selama ini telah memberikan kepercayaan kepada karang taruna untuk mengambil peran dalam setiap kegiatan. Walaupun yang bergabung dalam karang taruna ini bersifat sukarela, tetapi tidak menyurutkan semangat dan kebersamaan mereka. Hal ini terlihat ketika kegiatan sosialisasi dan pendampingan pembuatan bank sampah berlangsung, seluruh peserta yang hadir pada kegiatan tersebut masih tetap antusias sampai akhir sesi kegiatan.

Gambar 4 menunjukan bahwa Dusun Kluwih saat ini telah memiliki bank sampah dengan nama "Bank Sampah Kluwih Resik", dengan struktur pengurus Bank Sampah Kluwih Resik melibatkan anggota dari Karang Taruna Swayasatwika. Dalam kesempatan ini ketua tim pengabdi Dr. Ulung Pribadi juga menyampaikan apresiasinya atas terbentuknya Bank Sampah Kluwih Resik. Ada 5 hal yang menjadi poin utama terbentuknya Bank Sampah Kluwih Resik, diantaranya (1) dengan terbentuknya bank sampah di Dusun Kluwih ada aspek pemberdayaan masyarakat dengan melibatkan generasi muda untuk mengambil peran dalam pengelolaan sampah; (2) dengan adanya bank sampah, ada aspek ekonomi yang ikut berperan dalam mengajarkan hal baru kepada masyarakat yang biasa menabung menggunakan uang, kali ini menabung menggunakan sampah; (3) dengan adanya bank sampah, aspek lingkungan juga mempunyai peran sehingga masyarakat ikut menjaga kebersihan lingkungan agar Dusun Kluwih bisa menjadi Dusun yang terbebas dari sampah; (4) aspek sosial juga memiliki peran terhadap bank sampah, yaitu menumbuhkan rasa kebersamaan antarwarga Dusun Kluwih dalam pengelolaan sampah; dan (5) bagi masyarakat khususnya kalangan muda Dusun Kluwih ada aspek pendidikan yang menambah wawasan dan pengalaman mereka mengenai pengelolaan sampah dalam bank sampah.

Untuk saat ini keberadaan bank sampah Kluwih Resik bertujuan untuk menjadikan lingkungan Dusun Kluwih menjadi bersih, menyadarkan masyarakat akan pentingnya menjaga kebersihan, dan menjadikan sampah memiliki nilai ekonomis. Nantinya bank sampah Kluih Resik akan menjadi tabungan bagi masyarakat dan hasil tabungan tersebut bisa diambil, tidak hanya berupa uang, tetapi bisa berupa kebutuhan bahan pokok, seperti beras, mie instan, minyak, sabun, detergen, gula, pulsa, atau pasta gigi. Nantinya sampah-sampah yang disetorkan ke bank sampah Kluwih Resik dibedakan menjadi 


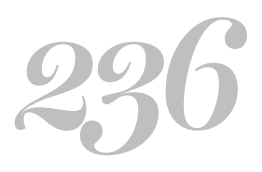

beberapa jenis, misalnya sampah organik, seperti potongan sayuran atau sisa masakan; mapun nonorganik seperti plastik, besi, dan lainnya.

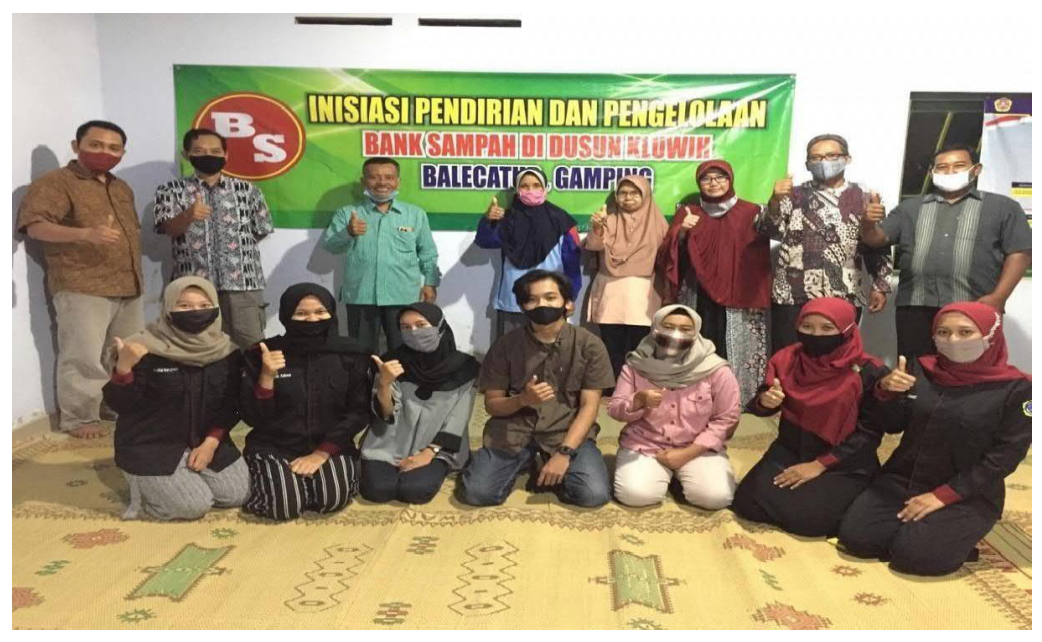

Gambar 5 : Foto Bersama Seluruh Peserta Kegiatan Sosialisasi \& Pendampingan Pembuatan Bank Sampah[BS8]

\section{SIMPULAN}

Pendirian dan pengelolaan bank sampah di Dusun Kluwih dengan nama "Bank Sampah Kluwih Resik", dengan struktur keanggotaannya berasal dari anggota Karang Taruna Swayasatwika dapat menumbuhkan kepedulian, partisipasi, semangat gotong royong warga, khususnya pada generasi muda Dusun Kluwih untuk mengambil peran dalam pengelolaan sampah[BS9]

\section{DAFTAR PUSTAKA}

E. Suryani. (2016). Manajemen Pengelolaan Bank Sampah di Kota Bekasi. Jurnal AKP, 6(1), 63-75. Kristina, H. J. (2014). Model Konseptual Untuk Mengukur Adaptabilitas Bank

Sampah Di Indonesia. Jurnal Teknik Industri, 9(1), 19-28.

Kusuma, D. P., \& Astuti, Y. (2017). Sistem Pengolahan Data Bank Sampah ( Study Kasus/ : Bank Sampah Bangkit Pondok I Ngemplak Sleman ). Jurnal Manajemen Dan Informatika Pelita Nusanta, 21(1), 32-41.
Safiah, \& Julipriyanto, W. (2017). Di Dusun Semali Desa Salamkanci Kecamatan Bandongan Kabupaten Magelang . ( Study Bank Sampah Semali Berseri ) The Benefit Of Bank Waste For Community In The Design Of The Villages In The Bandongan Sub District District Magelang. Jurnal REP (Riset Ekonomi Pembangunan), 2(2), 165-184.[BS11] 